\title{
PATENTWATCH
}

\section{Appreciating the invention}

In an appeal from a Maryland District Court decision invalidating many claims in three Invitrogen patents (US 5,244,797, $5,688,005$ and $6,063,608)$, the Court of Appeals for the Federal Circuit ruled that the law of appreciation was misapplied when determining the conception date of the invention by academic researchers who made the same invention. Conception requires that the inventor appreciate that which has been invented; evidence that the inventor understood the features of the creation is required. The Appellate court affirmed the District Court's rulings in Invitrogen's favour that Clontech's products infringe Invitrogen patents.

The Invitrogen patents relate to a genetically modified version of the enzyme reverse transcriptase, which is used to prepare $\mathrm{cDNA}$ libraries from mRNA templates. Wild-type reverse transcriptase has both DNA polymerase and RNase $\mathrm{H}$ activities, so during cloning the mRNA template is destroyed. By contrast, the genetically modified enzyme lacks RNase $\mathrm{H}$ activity, giving researchers the ability to reuse the mRNA template. The invention was reduced to practise in January 1987.

Two researchers at Columbia University, Stephen Goff and Naoko Tanese, had conceived of such an enzyme. In December 1984 Goff and Tanese prepared a panel of bacterial mutants with modified reverse transcriptase genes; this included two mutants that possessed modified reverse transcriptase lacking RNase $\mathrm{H}$ activity. However, this was not conclusively shown until the design of a new assay in March 1987 , which is when they started publishing their work. When they filed a patent application, the US Patent and Trademark Office (PTO) declared an interference between Goff and one of the Invitrogen applications. However, Goff's assignee, Columbia University, defaulted, and the PTO ruled in Invitrogen's favour. As a result, there was no determination of priority between the two parties; this is now the crux of the case, which depends on identifying the date when the Columbia researchers first appreciated that their two mutants had lost RNase $\mathrm{H}$ activity while retaining DNA polymerase activity.

The district court did not find that the research of Goff and Tanese anticipated Invitrogen's patents; however, the Federal Court ruled that the dates of conception established by the District Court were incorrect, because they did not account for appreciation, which could postpone the date of conception of December 1984. The case was remanded for further proceedings.

Melanie Brazil

Invitrogen Corp. v. Clontech Labs. Inc. No. 04-1039, -1040 (18 Nov 2005): http://www.fedcir.gov/opinions/04-1039.pdf 